\title{
IAMJ
}

INTERNATIONAL

AYURVEDIC

MEDICAL JOURNAL

ISSN: 2320-5091

Impact Factor: 6.719

\section{EVALUATION OF THE EFFECT OF UTTARABASTI AND MATRABASTI IN KLAIBYA W.S.R.TO ERECTILE DYSFUNCTION}

\section{Prakash Meti ${ }^{1}$, Lohith B $\mathbf{A}^{2}$}

${ }^{1}$ Associate Professor, Department of Panchakarma, Shri VeeraPulikeshi Rural Ayurvedic Medical College, Hospital and Research Centre, Badami, Karnataka, India

\& PhD Scholar, Dept. of Panchakarma, Shri Dharmasthala Manjunatheshwara College of Ayurveda and Hospital, Hassan, Karnataka, India

${ }^{2}$ Professor, Dept. of Panchakarma, Shri Dharmasthala Manjunatheshwara College of Ayurveda and Hospital, Hassan, Karnataka, India

Corresponding Author: drpsmeti@gmail.com

https://doi.org/10.46607/iamj02p5042021

(Published Online: May 2021)

Open Access

(C) International Ayurvedic Medical Journal, India 2021

Article Received:02/05/2021 - Peer Reviewed:06/05/2021 - Accepted for Publication:07/05/2021

Check for updates

\begin{abstract}
The condition in which loss or decrease in the capacity of normal erection with sufficient rigidity for penetrative intercourse is described as 'Klaibya'. It can be compared with Erectile dysfunction. Erectile dysfunction (ED) is a highly prevalent condition among men all over the world. It has a significant negative impact on the quality of life of the patients along with their partners. Hence to treat such condition many treatment modalities have been mentioned in Ayurveda among which Basti has prime role. In the present study Ashwagandha taila is used in the form of Uttarabasti and Matrabasti for 8 consecutive days to know its effect on Klaibya. Follow up of 16 days was done. The results were compared based on the subjective and objective parameters after 24 days. After assessing the parameters, it was observed that Group A Ashwagandha tailaUttarabasti has better role as compared to Group B Ashwagandha TailaMatrabasti in the management of Klaibya.
\end{abstract}

Keywords: Klaibya, Uttarabasti, Matrabasti, Ashwagandha Taila, Erectile Dysfunction 


\section{INTRODUCTION}

Among the various phases of sexual response, the most essential is the achieving of normal erection with sufficient rigidity for penetrative intercourse, the absence of which ends into failure and dissatisfaction. This condition has been elaborately described as 'Klaibya' in Ayurvedic classics and 'Erectile dysfunction' in modern texts.

Although Erectile dysfunction is a benign disorder, it affects physical and psychological health and has a significant impact on the quality of sufferers and their partners and families. In the National Health and Social Life Survey (NHSLS) the prevalence of sexual dysfunctions was $31 \%{ }^{1}$ It is estimated that in 1995 there were over 152 million men worldwide who had Erectile dysfunction, and in 2025 the number of men with Erectile dysfunction will be 322 million, an increase of nearly 170 million men. The greatest increase will be in the developing world, that is, Africa, Asia, and South America. ${ }^{2}$

The disease Klaibya is a multifactorial condition, mainly involving Bahu Doshavastha as a whole and Shukrakshaya in specific, Mano Dosha, and
ShukravahaSroto Dusti. ${ }^{3}$ Bastikarma has been doing wonders in the treatments of Ayurveda. Though it has been indicated for almost all the diseases, the prime importance of Bastikarma has been specified in the management of Klaibya.

Ashvagandhataila is mentioned as one of the Vajeekarana yoga in Chakradatta ${ }^{4}$ and in Bhaishajyaratnavali $^{5}$. It is also mentioned that Ashvagandhataila can be used in the form of Anuvasanabasti. Considering the grave nature of the disease though it does not reduce the life expectancy, it had been selected for the present study to find out a better cure

\section{Aim and Objectives}

- Evaluation of effect of Uttarabasti with Ashvagandhataila in Klaibya (erectile dysfunction)

- Evaluation of effect of Matrabasti with Ashvagandhataila in Klaibya (erectile dysfunction)

- To compare the efficacy of both Uttarabasti and Matrabasti with Ashvagandhataila in Klaibya (erectile dysfunction).

Materials and Methods:

A) Drugs: Ashwagandha Taila

\section{Ingredients}

Table 1: Showing the ingredients of AshvagandhaTaila:

\begin{tabular}{|c|c|c|c|}
\hline S.NO. & DRUGS & LATIN NAMES & QUANTITY \\
\hline 1 & Ashvagandha & Withaniasomnifera & 5 sera- $4.67 \mathrm{~kg}$ \\
\hline 2 & Jala (Water) & & 1 drona-12 litre \\
\hline 3 & Dugdha(Milk) & & 4 prastha-3.072 litre \\
\hline 4 & Taila (Tila) & Sesamum Indicum & 1 prastha- 0.768 litre \\
\hline 5 & $\begin{array}{l}\text { Kamalanala+kamalakanda }+ \text { kama- } \\
\text { la kosha }\end{array}$ & Nelumbo nucifera & $\begin{array}{l}\text { Remaining all are totally } \\
1 / 4^{\text {th }} \text { of taila }\end{array}$ \\
\hline 6 & Malatipushpa & Jasminum grandiflorum Linn. & \\
\hline 7 & Vribera & PavoniaodorataWilld. & \\
\hline 8 & Madhuka & Madhukaindica & \\
\hline 9 & Saariva & Hemidesmus indicus & \\
\hline 10 & Padmakesara & Prunus cirasoidus Linn. & \\
\hline 11 & Meda & Litseachinensis Lam. & \\
\hline 12 & Punarnava & Boerhaviadiffusa Linn. & \\
\hline 13 & Draksha & Vitis vinifera & \\
\hline 14 & Manjistha & Rubiacordifolia Linn. & \\
\hline 15 & Brihatidwaya & Solanum indicum + Tribulus terrestris & \\
\hline 16 & Ela & Elettariacardmomum & \\
\hline 17 & Elavalu & Gisekiapharnaceoides & \\
\hline
\end{tabular}




\begin{tabular}{|l|l|l|l|}
\hline 18 & Triphala & $\begin{array}{l}\text { Emblica officinalis +Terminalia beleri- } \\
\text { ca+Terminaliachebula }\end{array}$ & \\
\hline 19 & Mustha & Cyperusrotundus Linn. \\
\hline 20 & Chandana & Santalum alba Linn. \\
\hline 21 & Padmaka & Prunus cirasoidus Linn. \\
\hline
\end{tabular}

B) Patients: Total 30 patients diagnosed as Klaibya i.e. having Erectile dysfunction were selected for the clinical study.

\section{Source of Data}

Patient suffering from symptoms of Klaibya having erectile dysfunction were selected from O.P.D. of D.G.M.A.M.A.H. GADAG after fulfilling the inclusion and exclusion criteria.

\section{Literary}

Literary aspect of the study was collected from both ayurvedic as well as modern textbooks and updated with recent medical journals.

\section{- Selection of Drugs}

The trial drug was collected from Vyas pharmacy after being properly identified.

- Study Design

A comparative clinical study

- Sample Size:

Totally 34 patients were taken for study, 4 dropped out

Group A: 15 patients had received Uttarabasti with Ashvagandha Taila

Group B: 15 patients had received Matrabasti with Ashvagandhataila.

- Inclusive criteria

1. Patients with classical symptoms of Klaibya like Linga Shaithilya, Mlana Shishnata, MoghaSankalpa Chesta, Dhvajanucchraya, Suratasaktata.

\section{Study duration}

Group-A:

Uttarabasti karma - 8 days

Follow up - 16 days

Total duration $\quad-24$ days

2. Patients between the age group of 20 years to 50 years

3. Male sex

4. Patients who are fit for Uttarabasti

5. Patients who are fit for Matrabasti

- Exclusion criteria

1. Patients who are under concomitant therapy.

2. Patients who are unfit for Uttarabasti \& Matrabasti

3. Patients associated with other systemic disease.

4. Patients suffering from STD, Carcinoma, AIDS, TB, other disease like Phimosis, Ulceration, Hydrocele, Spinal cord lesions, etc.

5. Patients having congenital disorder of gonads.

Diagnostic criteria

- Diagnosis is made on the basis of classical symptoms of Klaibya like Linga Shaithilya, Mlana Shishnata, Mogha Sankalpa Chesta, Dhvajanucchraya, Suratasaktata and as Erectile dysfunction in modern texts

\section{Posology}

- Group- A: Uttarabasti with Ashvagandhataila 24 $\mathrm{ml}$ for 8 days

- Group-B: Matrabasti with Ashvagandhataila72 $\mathrm{ml}$ for 8 days

Method of administration of the Uttarabasti and Matrabasti with Ashvagandha Taila was done as per the classics.

\begin{tabular}{|c|c|}
\hline Group-B: & \\
\hline Matrabasti karma & - $\quad 8$ days \\
\hline Follow up & 16 days \\
\hline Total duration & 24 days \\
\hline
\end{tabular}

\section{Group-B:}

Assessment of results: The subjective and objective parameters of base line data to pre and post medication were compared for assessment of results. All the result will be analyzed statistically for 'p' value using unpaired and paired ' $t$ ' test. 


\section{Criteria for Assessment of Results}

Subjective Criteria:

\begin{tabular}{|l|l|l|}
\hline Domain & Questions \# & Total score \\
\hline Erectile Function & $1,2,3,4,5,15$ & \\
\hline Orgasmic Function & 9,10 & \\
\hline Sexual Desire & 11,12 & \\
\hline Intercourse Satisfaction & $6,7,8$ & \\
\hline Overall Satisfaction & 13,14 & \\
\hline
\end{tabular}

\section{Clinical Interpretation}

I. Erectile function total scores can be interpreted as follows:

Score Interpretation

0-6 Severe dysfunction

7-12 Moderate dysfunction

13-18 Mild to moderate dysfunction

$19-24$

25-30
$3-4$

$5-6$

$7-8$

$9-10$

IV. Intercourse satisfaction total scores can be interpreted as follows:

$\begin{array}{ll}\text { Score } & \text { Interpretation } \\ 0-3 & \text { Severe dysfunction } \\ 4-6 & \text { Moderate dysfunction } \\ 7-9 & \text { Mild to moderate dysfunction } \\ 10-12 & \text { Mild dysfunction } \\ 13-15 & \text { No dysfunction }\end{array}$

V. Overall satisfaction total scores can be interpreted as follows:

$\begin{array}{ll}\text { Score } & \text { Interpretation } \\ 0-2 & \text { Severe dysfunction } \\ 3-4 & \text { Moderate dysfunction } \\ 5-6 & \text { Mild to moderate dysfunction } \\ 7-8 & \text { Mild dysfunction } \\ 9-10 & \text { No dysfunction }\end{array}$

Moderate dysfunction

Mild to moderate dysfunction

Mild dysfunction

No dysfunction

II. Orgasmic function total scores can be interpreted as follows:

Score Interpretation

0-2 Severe dysfunction

3-4 Moderate dysfunction

5-6 Mild to moderate dysfunction

7-8 Mild dysfunction

9-10 No dysfunction

III. Sexual desire total scores can be interpreted as follows:

Score Interpretation

$0-2$

Severe dysfunction

\section{RESULT}

Table 2: Showing the comparative effect of treatment on subjective parameters in Group A and Group B

\begin{tabular}{|c|c|c|c|c|c|c|}
\hline PARAMETER & GROUP & Mean & SD & T-Value & P-Value & Remarks \\
\hline \multirow[t]{2}{*}{ Lingashaithilya } & A & 0.4 & 0.507 & \multirow[t]{2}{*}{2.127} & \multirow[t]{2}{*}{$<0.05$} & \multirow[t]{2}{*}{$\mathrm{S}$} \\
\hline & B & 0.33 & 0.487 & & & \\
\hline \multirow[t]{2}{*}{ Moghsankalpachesta } & A & 0.33 & 0.487 & \multirow[t]{2}{*}{0.787} & \multirow[t]{2}{*}{$>0.05$} & \multirow[t]{2}{*}{ NS } \\
\hline & B & 0.2 & 0.414 & & & \\
\hline \multirow{2}{*}{ Erectile function } & A & 3.46 & 1.18 & \multirow{2}{*}{3.07} & \multirow{2}{*}{$<0.01$} & \multirow{2}{*}{ HS } \\
\hline & B & 2.4 & 0.63 & & & \\
\hline \multirow{2}{*}{ Intercourse satisfaction } & A & 1.86 & 1.3 & \multirow{2}{*}{1.07} & \multirow{2}{*}{$>0.05$} & \multirow[t]{2}{*}{ NS } \\
\hline & B & 1.46 & 0.63 & & & \\
\hline \multirow{2}{*}{ Orgasmic function } & A & 0.33 & 0.487 & \multirow{2}{*}{0.406} & \multirow{2}{*}{$>0.05$} & \multirow{2}{*}{ NS } \\
\hline & B & 0.26 & 0.457 & & & \\
\hline \multirow[t]{2}{*}{ Sexual desire } & A & 0.2 & 0.414 & \multirow[t]{2}{*}{0} & \multirow[t]{2}{*}{$>0.05$} & \multirow[t]{2}{*}{ NS } \\
\hline & B & 0.2 & 0.414 & & & \\
\hline \multirow{2}{*}{ Overall satisfaction } & A & 0.26 & 0.457 & \multirow[t]{2}{*}{0.377} & \multirow[t]{2}{*}{$>0.05$} & \multirow[t]{2}{*}{ NS } \\
\hline & B & 0.2 & 0.414 & & & \\
\hline
\end{tabular}


To compare the subjective effectiveness of the treatment procedure between the two groups, the statistical analyses is done by using Un-paired t-test, by assuming that the mean effect treatment procedures is same in both the groups after treatment procedure.
From the analyses, it is clear that only the parameters Linga Shaithilya and Erection function have shown significant and highly significant result respectively. Remaining all the factors went not significant statistically.

Table 3: Showing the comparative effect of treatment on Objective parameters in Group A and Group B

\begin{tabular}{|c|c|c|c|c|c|c|}
\hline PARAMETER & GROUP & Mean & SD & T-Value & P-Value & Remarks \\
\hline \multirow[t]{2}{*}{ Desire for Sex } & A & 0.4 & 0.63 & \multirow[t]{2}{*}{0.341} & \multirow[t]{2}{*}{$>0.05$} & \multirow[t]{2}{*}{ NS } \\
\hline & B & 0.33 & 0.487 & & & \\
\hline \multirow[t]{2}{*}{ Penile Erection } & A & 0.66 & 0.61 & \multirow[t]{2}{*}{0.990} & \multirow[t]{2}{*}{$>0.05$} & \multirow[t]{2}{*}{ NS } \\
\hline & B & 0.46 & 0.49 & & & \\
\hline \multirow[t]{2}{*}{ Penile Rigidity } & A & 0.4 & 0.5 & \multirow[t]{2}{*}{0.393} & \multirow[t]{2}{*}{$>0.05$} & \multirow[t]{2}{*}{ NS } \\
\hline & B & 0.33 & 0.48 & & & \\
\hline \multirow[t]{2}{*}{ Ejaculation } & A & 0.33 & 0.48 & \multirow[t]{2}{*}{0.414} & \multirow[t]{2}{*}{$>0.05$} & \multirow[t]{2}{*}{ NS } \\
\hline & B & 0.26 & 0.45 & & & \\
\hline \multirow[t]{2}{*}{ Orgasm } & A & 0.266 & 0.45 & \multirow[t]{2}{*}{0.853} & \multirow[t]{2}{*}{$>0.05$} & \multirow[t]{2}{*}{ NS } \\
\hline & B & 0.4 & 0.414 & & & \\
\hline \multirow[t]{2}{*}{ Volume } & A & 0.31 & 0.47 & \multirow[t]{2}{*}{1.542} & \multirow[t]{2}{*}{$>0.05$} & \multirow[t]{2}{*}{ NS } \\
\hline & B & 0.04 & 0.49 & & & \\
\hline \multirow[t]{2}{*}{ Sperm concentration } & A & 12.6 & 18.8 & \multirow[t]{2}{*}{1.595} & \multirow[t]{2}{*}{$>0.05$} & \multirow[t]{2}{*}{ NS } \\
\hline & B & 4.45 & 6.18 & & & \\
\hline \multirow[t]{2}{*}{ Total Sperm count } & A & 12.9 & 19.5 & \multirow[t]{2}{*}{1.769} & \multirow[t]{2}{*}{$>0.05$} & \multirow[t]{2}{*}{ NS } \\
\hline & B & 3.56 & 6.15 & & & \\
\hline \multirow[t]{2}{*}{ Total motility } & A & -1.53 & 19.61 & \multirow[t]{2}{*}{1.157} & \multirow[t]{2}{*}{$>0.05$} & \multirow[t]{2}{*}{ NS } \\
\hline & B & 5.16 & 10.84 & & & \\
\hline
\end{tabular}

To compare the objective effectiveness of the treatment procedure between the two groups, the statistical analyses is done by using Un-paired t-test, by assuming that the mean effect of the treatment procedures is same in both the groups after treatment procedure.
From the analysis all the parameters shown nonsignificant (as $\mathrm{P}>0.05$ ). i.e., the mean effect of the treatment procedure is same in both the groups.

Table 4: Effect of Ashvagandha Taila Uttarabasti On Subjective Parameters of Group A

\begin{tabular}{|c|c|c|c|c|c|c|c|c|}
\hline \multirow[t]{2}{*}{ PARAMETER } & \multicolumn{2}{|c|}{ MEAN } & \multirow{2}{*}{$\begin{array}{l}\text { Net } \\
\text { Mean }\end{array}$} & \multirow[t]{2}{*}{ SD } & \multirow[t]{2}{*}{$\mathrm{SE}$} & \multirow{2}{*}{$\begin{array}{l}\text { T- } \\
\text { Value }\end{array}$} & \multirow[t]{2}{*}{ P-Value } & \multirow[t]{2}{*}{ Remarks } \\
\hline & AT & BT & & & & & & \\
\hline Lingashaithilya & 2.93 & 2.53 & 0.4 & 0.507 & 0.131 & 3.05 & $<0.01$ & HS \\
\hline Moghasankalpachesta & 2.53 & 2.2 & 0.33 & 0.487 & 0.125 & 2.64 & $<0.05$ & $\mathrm{~S}$ \\
\hline Erectile function & 22.06 & 18.6 & 3.46 & 1.18 & 0.304 & 11.3 & $<0.001$ & HS \\
\hline Intercourse satisfaction & 11.9 & 10.0 & 1.86 & 1.3 & 0.335 & 5.55 & $<0.001$ & HS \\
\hline Orgasmic function & 6.8 & 6.46 & 0.33 & 0.487 & 0.125 & 2.64 & $<0.05$ & $\mathrm{~S}$ \\
\hline Sexual desire & 7.6 & 7.4 & 0.2 & 0.414 & 0.107 & 1.87 & $>0.05$ & NS \\
\hline Overall satisfaction & 6.06 & 5.8 & 0.26 & 0.45 & 0.116 & 2.25 & $<0.05$ & $\mathrm{~S}$ \\
\hline
\end{tabular}

To know about the which subjective factors among From the analysis it is clear that the parameters Linga Group A are more effective, the statistical analyses is done by using paired t-test, by assuming that the drug is not responsible for changes in before and after the Uttarabasti with Ashvagandhataila. Shaithilya, Erectile function and Intercourse satisfaction are highly significant, the parameters Moghasankalpachesta, Orgasmic function and Overall satisfaction are statistically significant, whereas Sexual desire is statistically not significant. 
Table 5: Showing the effect of Ashvagandhatailamatrabasti on subjective parameters: GROUP B

\begin{tabular}{|l|l|l|l|l|l|l|l|l|}
\hline \multirow{2}{*}{ PARAMETER } & MEAN & Net & SD & SE & $\begin{array}{l}\text { T- } \\
\text { Value }\end{array}$ & P- Value & Remarks \\
\cline { 2 - 9 } & AT & BT & Mean & & & & \\
\hline Lingashaithilya & 2.8 & 2.46 & 0.33 & 0.487 & 0.125 & 2.64 & $<0.05$ & S \\
\hline Moghsankalpachesta & 2.2 & 2 & 0.2 & 0.414 & 0.107 & 1.87 & $>0.05$ & NS \\
\hline Erectile function & 20.66 & 18.26 & 2.4 & 0.63 & 0.162 & 14.69 & $<0.001$ & HS \\
\hline Intercourse satisfaction & 11.33 & 9.86 & 1.46 & 0.63 & 0.162 & 8.87 & $<0.001$ & HS \\
\hline Orgasmic function & 6.2 & 5.93 & 0.26 & 0.45 & 0.116 & 2.25 & $<0.05$ & S \\
\hline Sexual desire & 6.93 & 6.73 & 0.2 & 0.414 & 0.107 & 1.87 & $>0.05$ & NS \\
\hline Overall satisfaction & 6.2 & 6 & 0.2 & 0.414 & 0.107 & 1.87 & $>0.05$ & NS \\
\hline
\end{tabular}

To know about the which subjective factors among Group B are more effective, the statistical analyses is done by using paired t-test, by assuming that the drug is not responsible for changes in before and after the Matrabasti with Ashvagandhataila.
From the analysis it clear that the parameters Erectile function and Intercourse satisfaction are highly significant, the parameters LingaShaithilya, Moghasankalpachesta and Orgasmic function are statistically significant, whereas Sexual desire and Overall satisfaction are statistically not significant.

Table 6: Showing the effect of ashvagandhatailaUttarabasti on objective parameters: GROUP A

\begin{tabular}{|l|l|l|l|l|l|l|l|l|}
\hline \multirow{2}{*}{ PARAMETER } & \multicolumn{2}{|l|}{ MEAN } & Net & SD & SE & $\begin{array}{l}\text { T- } \\
\text { Value }\end{array}$ & P- Value & Remarks \\
\cline { 2 - 10 } & AT & BT & Mean & & & & \\
\hline Desire for Sex & 1.73 & 1.33 & 0.4 & 0.63 & 0.162 & 2.44 & $<0.05$ & S \\
\hline Penile Erection & 3.13 & 2.46 & 0.66 & 0.61 & 0.157 & 4.18 & $<0.001$ & HS \\
\hline Penile Rigidity & 2.33 & 1.93 & 0.4 & 0.50 & 0.129 & 3.05 & $<0.01$ & HS \\
\hline Ejaculation & 2.8 & 2.46 & 0.33 & 0.48 & 0.124 & 2.64 & $<0.05$ & S \\
\hline Orgasm & 2.33 & 2.06 & 0.266 & 0.45 & 0.116 & 2.25 & $<0.05$ & S \\
\hline Volume & 1.37 & 1.06 & 0.31 & 0.47 & 0.121 & 2.38 & $<0.05$ & S \\
\hline Sperm concentration & 40.8 & 28.2 & 12.6 & 18.8 & 4.85 & 2.41 & $<0.05$ & S \\
\hline Total Sperm count & 35.9 & 23.0 & 12.9 & 19.5 & 5.03 & 2.37 & $<0.05$ & S \\
\hline Total motility & 53.07 & 54.61 & -1.53 & 19.61 & 5.06 & 0.28 & $>0.05$ & NS \\
\hline
\end{tabular}

To know about the which objective factors among Group A are more effective, the statistical analyses is done by using paired t-test, by assuming that the drug is not responsible for changes in before and after the Uttarabasti with Ashvagandhataila.
From the analysis it is clear that the parameters Penile Erection and Penile Rigidity are highly significant, the parameters Desire for sex, Ejaculation, Orgasm, Semen Volume, Sperm concentration, and Total sperm count are statistically significant, where as Total motility is statistically not significant.

Table 7: Showing the effect of Ashvagandhatailamatrabasti on objective parameters: GROUP B

\begin{tabular}{|l|l|l|l|l|l|l|l|l|}
\hline \multirow{2}{*}{ PARAMETER } & \multicolumn{2}{|l|}{ MEAN } & Net & SD & SE & $\begin{array}{l}\text { T- } \\
\text { Value }\end{array}$ & P- Value & Remarks \\
\cline { 2 - 9 } & AT & BT & Mean & & & & \\
\hline Desire for Sex & 2.06 & 1.73 & 0.33 & 0.487 & 0.125 & 2.64 & $<0.05$ & S \\
\hline Penile Erection & 2.86 & 2.4 & 0.46 & 0.49 & 0.126 & 3.74 & $<0.01$ & HS \\
\hline Penile Rigidity & 2.33 & 2 & 0.33 & 0.48 & 0.124 & 2.64 & $<0.05$ & S \\
\hline
\end{tabular}




\begin{tabular}{|l|l|l|l|l|l|l|l|l|}
\hline Ejaculation & 2.8 & 2.53 & 0.26 & 0.45 & 0.116 & 2.25 & $<0.05$ & $\mathrm{~S}$ \\
\hline Orgasm & 2.46 & 2.26 & 0.4 & 0.414 & 0.107 & 1.87 & $>0.05$ & NS \\
\hline Volume & 1.20 & 1.16 & 0.04 & 0.49 & 0.126 & 0.28 & $>0.05$ & NS \\
\hline Sperm concentration & 45.18 & 40.72 & 4.45 & 6.18 & 1.59 & 2.38 & $<0.05$ & S \\
\hline Total Sperm count & 38.5 & 34.9 & 3.56 & 6.15 & 1.58 & 2.00 & $>0.05$ & NS \\
\hline Total motility & 67.5 & 62.33 & 5.16 & 10.84 & 2.80 & 1.65 & $>0.05$ & NS \\
\hline
\end{tabular}

To know about the which objective factors among Group B are more effective, the statistical analyses is done by using paired t-test, by assuming that the drug is not responsible for changes in before and after the Uttarabasti with Ashvagandhataila.

From the analysis it is clear that the parameters Penile Erection is highly significant, the parameters Desire for sex, Penile Rigidity, Ejaculation and Orgasm are significant. Semen Volume, Sperm concentration, Total sperm count and Total motility are statistically not significant.

- Out of total 16 parameters Group B showed better results in 4 factors, whereas remaining 12 factors were dominated by the Group A. Hence comparatively Group A Uttarabasti with Ashvagandha Taila is having better result than the Group B Matrabasti with Ashvagandha Taila.

- Statistically there is no difference in the mean effect of the two procedures over the objective parameters of Klaibya whereas only Lingashaithilya and Erectile function parameters had the significant difference in the mean effect of the therapy on subjective parameters of Klaibya.

\section{DISCUSSION}

The chief factors causing the condition Klaibya are Vata, Dhatukshaya in general and Shukrakshaya in particular, Shukravaha Strotodusti, Marmaghata and Mano Dosha. Vata is responsible for all the Chesta, particularly of the Indriyas viz. Jnanendriya, Karmendriya and Manas. The functioning of these Indri$y a$ in harmony is the key for normal sexual functioning. The aggravated Vata particularly the Prana, Vyana and Apana causes the impairment in the functioning of these Indriyas.

Further the vigor is most essential thing to perform any functions, and it entirely depends upon the opti- mum quantity of Dhatu having good quality in general and Shukra in particular, specially it holds good for indulgence in sexual intercourse. Hence the deprivation of the Dhatu is considered as cause for Klaibya. Before giving Uttara Basti, Niroohabasti is indicated in the classics. It indicates that Kostha Shodhan, Vatanulomana and Rookshana Chikitsa are essential before Snehana Chikitsa like Uttara basti. But for the convenience of the study and for research purpose I have restricted my study only to Uttarabasti without any type of Niruhabasti.

\section{Probable mode of Action:}

Ashvagandha Taila possesses Vrushya, Balya, Medhya, Vatahara, Rasayana, Vajeekarana, Pachana and Deepana properties. As Vrushya and Balya the drug enhances the quality of Shukradhatu reducing Dourbalya and Riktata in Shukravahasrotas thus by pacifies the aggravated Vata. Medhya properties of the drugs act biologically and improve the psychological functioning. The Shukrastambhaka property by virtue of decreasing Saratva of Shukra Dhatus and enhancing sthiratva helps in the retention of semen for longer duration. It also improves the strength of the individual by balya property helps in sexual functioning as Harshashakti depends on Dehabala also.

On pharmacological analysis the constituents of the drugs were especially psychotropic, antianxiolytic, aphrodisiac, mood elevators and reduce hyper excitability. This helps to control the attainment of steep curve arousal and plateau phase of sexual response cycle.

Dropouts: Patients were selected for the clinical study between the age group 20-50 years, A Total of 4 patients were dropped out from the study. 3 in Group A i.e. in Uttarabasti group and one patient from the Group B i.e. Matrabasti group. 
Out of those 3 patients of dropped out in Group A, two patients had developed urinary tract infection after $2^{\text {nd }}$ and $4^{\text {th }}$ day of Uttarabasti administration respectively.

The reason may be because of not maintaining the proper hygienic and asceptic precautions. During such instance I had gone through the details of Uttarabasti instruments and their condition asceptic measures, finally I got to know that Folley`s catheter using for those patients were not cleaned properly. Because of which even after subjecting the instruments to autoclave the patients developed urinary tract infection. Since then an extra care was taken to see that all the things there within asceptic condition.

Remaining one patient of drop out the reason found that, he was not comfortable with the mode of administration. He had left the treatment by $3^{\text {rd }}$ day and insisted for the oral medication.

In group B one patient of dropped out had also the same sort hesitation to undergo the treatment. Hence, he was also insisting for the oral medication and left trial study by $5^{\text {th }}$ day of Matrabasti.

\section{CONCLUSION}

- Uttarabasti with Ashvagandhataila has very good effect over the Linga Shaithilya, Erectile function, Intercourse satisfaction, Penile Erection and Penile Rigidity parameters

- Matrabasti with Ashvagandhataila has very good effect over the Erectile function and Intercourse satisfaction parameters and Penile Erection parameters.

- Out of total 16 parameters Group B showed better results in 4 factors, whereas remaining 12 factors were dominated by the Group A. Hence comparatively Group A Uttarabasti with Ashvagandha Taila is having better result than the Group B Matrabasti with Ashvagandha Taila.

- Statistically there is no difference in the mean effect of the two procedures over the objective parameters of Klaibya whereas only Lingashaithilya and Erectile function parameters had the significant difference in the mean effect of the therapy on subjective parameters of Klaibya.

\section{REFERENCES}

1. Hatzimouratidis K, Amar E, Eardley I, Giuliano F, Hatzichristou D, Montorsi F, et al. Guidelines on male sexual dysfunction and premature ejaculation. Eur Urol 2010;57;804-14

2. Rehman S. Erectile dysfunction: Prevalence, incidence and risk factors, Academic dissertation, University of Tampere: 2004

3. Acharya P.V. Sharma and forwarded by Yadavji Trikramji, Charakasamhitha, Part II, Chikithsasthana $30^{\text {th }}$ chapter- $138^{\text {th }}$ sloka, $8^{\text {th }}$ edition 2004 , Chaukamba sanskritsansthan, Varanasi, page no-770

4. Priya Vrat Sharma edited Chakradatta, $22^{\text {nd }}$ chapter, shloka no-142-46, $1^{\text {st }}$ edtition-1994, Choukamba Orientalia, Varanasi, page no-199

5. Sri Brahmashankara Mishra, Bhaishajya Ratnavali, $26^{\text {th }}$ chapter, shloka no-284-88, $18^{\text {th }}$ revised edition-2005, Choukamba Sanskrit Sansthan, Varanasi, page no-556.

\section{Source of Support: Nil Conflict of Interest: None Declared}

How to cite this URL: Prakash Meti \& Lohith B A: Evaluation Of The Effect Of Uttarabasti And Matrabasti In Klaibya W.S.R.To Erectile Dysfunction. International Ayurvedic Medical Journal \{online\} 2021 \{cited May, 2021\} Available from: http://www.iamj.in/posts/images/upload/2880_2887.pdf 